\title{
PRAKTEK PEMBEBANAN DAN PELAKSANAAN EKSEKUSI HAK TANGGUNGAN DI INDONESIA
}

\author{
Prof. Ny. Arie Hutagalung ${ }^{1}$
}

\begin{abstract}
Abstrak
This article elaborates concerning Indonesia secured transcation that focused on hak tanggungan (Indonesian mortgage) in anxious practical perspectives. The origin of the apprehension is rooted on the regulation method of foreclosure hak tanggungan. The regulation itself that abide by prior Dutch law (HIR dan Rbg) has reflected inconsistency on Indonesian secured transcation law refom. That divergence is reflected by their long distance era perspectives and unsimilar concern which is HIR and Rbg commonly effective for civil procedure that then has not sophisticated on hak tanggungan foreclosure. The most significant anxious implication at practice area has been resulted by divergence happens on foreclosure procedure. Under article 6 Hak Tanggungan Law foreclosure can be done by parate executie (selling by granted proxy) methods, but then be released by pargraph 9 of General Eludication that stipulate any fiat executie (court order). That situation is continuing in practice even by Law number 10 year 2004 has released stipulation that eludication of law has no tight bind and effective power.
\end{abstract}

Kata kunci: hukum agraria, hak tanggungan, permasalahan, praktek pelaksanaan eksekusi

\section{Pendahuluan}

Pembangunan ekonomi, sebagai bagian dari pembangunan nasional merupakan salah satu upaya untuk mewujudkan kesejahteraan rakyat yang adil dan makmur berdasarkan Pancasila dan Undang-Undang Dasar 1945. Dalam rangka memelihara kesinambungan pembangunan tersebut, para pelaku usaha memerlukan sejumlah dana yang tidak sedikit sebagai modal usaha. Seiiring dengan perkembangan zaman, sebagian dana diperoleh melalui kegiatan perkreditan. Dalam pelaksanaan pemberian kredit tersebut diperlukan suatu lembaga jaminan guna melindungi kepentingan para pihak baik pihak pemberi kredit (kreditur) maupun penerima kredit (debitur).

\footnotetext{
' Guru Besar Hukum Agraria Fakultas Hukum Universitas Indonesia.
} 
Sebelum berlakunya Undang-Undang Nomor 5 Tahun 1960 Tentang Peraturan Dasar Pokok-Pokok Agraria (UUPA) terdapat dualisme dalam hukum pertanahan yaitu pengaturan yang terdapat dalam Hukum Adat seperti hak ulayat, hak milik, hak gogolan, dan lain-lain; dan Hukum Perdata Barat seperti eigendom, erfpacht, opstal. Dualisme tersebut juga berakibat pada dualisme sistem hukum jaminan seperti hypotheek dan credietverband. Hypotheek digunakan sebagai jaminan atas hak-hak atas tanah yang tunduk pada Hukum Perdata Barat, sedangkan Credietverband digunakan sebagai jaminan atas hak-hak atas tanah yang tunduk pada Hukum Adat. ${ }^{2}$

Setelah berlakunya UUPA, perihal lembaga hak jaminan yang kuat yang dapat dibebankan pada hak atas tanah, yaitu Hak Tanggungan (HT) sebagai pengganti lembaga Hypotheek dan Credietverband diatur dalam Pasal 51 UUPA. Selama 30 tahun lebih sejak mulai berlakunya UUPA, lembaga HT di atas belum dapat berfungsi sebagaimana mestinya, karena belum adanya Undang-Undang yang mengaturnya secara lengkap, sesuai yang dikehendaki oleh ketentuan Pasal 51 UUPA. Dalam kurun waktu itu, berdasarkan ketentuan peralihan yang tercantum dalam Pasal 57 UUPA, masih diberlakukan ketentuan Hypotheek sebagaimana dimaksud dalam Buku II Kitab Undang-Undang Hukum Perdata Indonesia (KUHPerdata) dan ketentuan Credietverband dalam Staatsblad 1908-542 sebagaimana telah diubah dengan Staatsblad 1937-190, sepanjang mengenai hal-hal yang belum ada ketentuannya dalam atau berdasarkan UUPA. ${ }^{3}$

Dengan semakin majunya perkembangan perekonomian khususnya dalam hal perkreditan maka diperlukannya pengaturan mengenai lembaga jaminan HT sebagai lembaga jaminan atas tanah berdasarkan Pasal 51 UUPA. Sehingga, Pada 9 April 1996, lahirlah lembaga jaminan HT dengan dikeluarkannya Undang-Undang Nomor 4 Tahun 1996 Tentang Hak Tanggungan Atas Tanah Beserta Benda-Benda Yang Berkaitan Dengan Tanah (UUHT). Dengan lahirnya UUHT tersebut, HT merupakan satusatunya lembaga hak jaminan atas tanah dalam Hukum Tanah Nasional yang tertulis.

Pelaksanaan pembebanan lembaga jaminan HT di atas hak-hak atas tanah tersebut harus didahului dengan perjanjian pokok yaitu perjanjian utang piutang yang kemudian dibuat perjanjian jaminan HT atas hak atas tanah beserta benda-benda yang terkait diatasnya, yang disebut dengan

2 Iming Tesalonika, "Indonesian Security Interest", (Tangerang: Pusat Hukum Bisnis Universitas Pelita Harapan, 2001), hal. 39.

${ }^{3}$ Penjelasan Umum Angka 2 atas Undang-Undang Republik Indonesia Nomor 4 Tahun 1996 Tentang Hak Tanggungan Atas Tanah Beserta Benda-Benda Yang Berkaitan Dengan Tanah. 
perjanjian accesoir. Pembebanan HT tersebut berguna bagi pelaksanaan penyaluran dana kredit apabila debitur wanprestasi dan akan dilakukan eksekusi terhadap debitur yang wanprestasi.

Pelaksanaan eksekusi HT tersebut masih menggunakan produk hukum Belanda yaitu Het Herziene Indonesisch Reglement (HIR) untuk daerah Jawa dan Madura dan Reglement tot Regeling van het Rechtswezen in de Gewesten Buiten Java en Madura (RBg.) untuk daerah di Luar Jawa dan Madura. Hal tersebut menimbulkan hambatan-hambatan atau permasalahan-permasalahan dalam pelaksanaan eksekusi HT dikarenakan hukum acara yang digunakan sudah tidak sesuai lagi dengan perkembangan zaman saat ini. Dengan demikian, diperlukannya produk hukum baru yang secara khusus mengatur mengenai eksekusi tersebut. Selain itu, terdapat inkonsistensi penjelasan mengenai pelaksanaan parate executie atas obyek HT yang tertuang dalam Pasal 6 UUHT dengan Penjelasan Umum Angka 9 UUHT yang menyatakan bahwa pelaksanaan parate executie dilaksanakan berdasarkan Pasal 224 HIR dan Pasal 258 RBg.

\section{Hak Tanggungan}

\section{A. Pengertian}

Hak Tanggungan adalah hak jaminan yang dibebankan pada hak atas tanah sebagaimana dimaksud dalam UUPA, berikut atau tidak berikut benda-benda lain yang merupakan satu kesatuan dengan tanah itu, untuk pelunasan utang tertentu, yang memberikan kedudukan yang diutamakan kepada kreditur tertentu terhadap kreditur-kreditur lain (Pasal 1 Ayat (1) UUHT).

Selain pengertian tersebut, berdasarkan Penjelasan Umum Angka (3) UUHT menyatakan bahwa lembaga jaminan HT mempunyai ciri-ciri sebagai berikut:

1. Memberi kedudukan yang diutamkaan kepada krediturnya (droit de preference);

2. Selalu mengikuti obyek yang dijaminkan di tangan siapapun obyek itu berada (droit de suite);

3. Memenuhi asas spesialitas dan asas publisitas sehingga dapat mengikat para pihak ketiga dan memberikan kepastian hukum pada pihak-pihak yang berkepentingan;

4. Mudah dan pasti pelaksanaannya eksekusi. 


\section{B. Objek Hak Tanggungan}

Tanah-tanah dan benda-benda yang berkaitan dengan tanah yang akan dibebani dengan HT harus memenuhi persyaratan sebagai obyek HT, persyaratan-persyaratan tersebut adalah sebagai berikut:

1. Dapat dinilai dengan uang, karena utang yang dijamin berupa uang;

2. Mempunyai sifat dapat dipindahtangankan, karena apabila debitur cidera janji benda yang dijadikan jaminan akan dijual;

3. Termasuk hak yang di daftar menurut peraturan tentang pendaftaran tanah yang berlaku, karena harus memenuhi asas publisitas;

4. Memerlukan penunjukan khusus oleh suatu undang-undang. ${ }^{4}$

Sehubungan dengan persyaratan-persyaratan tersebut, Pasal 4 UUHT menetapkan obyek Hak Tanggungan sebagai berikut:

1. Hak Milik, Hak Guna Usaha, Hak Guna Bangunan;

2. Hak Pakai atas Tanah Negara, yang menurut ketentuan yang berlaku wajib di daftar dan menurut sifatnya dapat dipindahtangankan;

3. Hak atas tanah berikut bangunan, tanaman dan hasil karya yang telah ada atau akan ada yang merupakan milik pemegang hak atas tanah yang pembebanannya dengan tegas dinyatakan dalan Akta Pemberian Hak Tanggungan (APHT) yang bersangkutan. Apabila bangunan, tanaman dan hasil karya tidak dimiliki oleh pemegang hak atas tanah, pembebasan HT dilakukan dengan penandatanganan serta pada APHT yang bersangkutan oleh pemiliknya atau yang diberi kuasa untuk itu olehnya dengan akta otentik;

4. Bangunan Rumah Susun dan Hak Milik Atas Satuan Rumah Susun (HMSRS) yang berdiri di atas tanah HM, HGB, atau Hak Pakai yang diberikan oleh Negara (Pasal 27 jo UU 16/1985).

\section{Perjanjian}

Perjanjian menurut Subekti adalah suatu peristiwa dimana seorang berjanji pada seorang lain atau di mana dua orang itu saling berjanji untuk melaksanakan sesuatu hal. ${ }^{5}$

${ }^{4}$ Boedi Harsono, "Sejarah Pembentukan Undang-Undang Pokok Agraria, Isi dan Pelaksanaannya", (Jakarta: Djambatan, 2005), hal. 422. 
Perjanjian tersebut menimbulkan hak dan kewajiban bagi para pihak, apabila terjadi sesuatu maka salah satu pihak dapat menuntut hak dan kewajiban kepada pihak lainnya yang terikat dengan perjanjian. Begitu pula, dengan perjanjian kredit atau perjanjian utang - piutang antara pihak kreditur dengan pihak debitur yang sudah dijamin dengan harta benda debitur, ${ }^{6}$ maka apabila pihak debitur tidak dapat memenuhi kewajibannya untuk membayar utang berdasarkan Pasal 1131 KUHPerdata harta debitur akan dijadikan jaminan dengan cara pihak kreditur memohon kepada hakim untuk menjual harta benda debitur untuk dijual secara lelang dan hasil penjualannya akan dijaminkan untuk melunasi hutang tersebut, akan tetapi membutuhkan banyak waktu yang lama dan biaya serta proses yang berbelit-belit. ${ }^{7}$

Selain itu, perlindungan bagi pihak kreditur juga diatur dalam Pasal 1132 KUHPerdata yang menyebutkan bahwa benda tersebut menjadi jaminan bersama-sama bagi semua orang yang menguntungkan padanya, pendapatan penjualan benda-benda itu dibagi-bagi menurut keseimbangannya, yaitu menurut besar kecilnya piutang masing-masing, kecuali apabila diantara yang berpiutang tersebut ada alasan yang sah untuk didahulukan. ${ }^{8}$

Perjanjian utang - piutang yang dilakukan oleh pihak kreditur dan pihak debitur tersebut merupakan perjanjian pokok yang lazimnya diikuti dengan perjanjian jaminan sebagai perjanjian tambahan (accesoir) dari perjanjian utang-piutang tersebut. Selain itu, dalam UUHT juga ditegaskan perihal perjanjian pemberian HT merupakan perjanjian yang bersifat accesoir, hal tersebut dijelaskan dalam Penjelasan Umum Angka 8 UUHT yang berbunyi:

Oleh karena HT menurut sifatnya merupakan ikutan atau accesoir pada suatu piutang tertentu, yang didasarkan pada satu perjanjian utang piutang atau perjanjian lain, maka kelahiran dan keberadaannya ditentukan oleh adanya piutang yang dijamin pelunasannya. Apabila piutang tersebut beralih kepada kreditur lain, maka HT yang

${ }^{5}$ Subekti, "Hukum Perjanjian", Cetakan ke-X, (Jakarta: PT. Intermasa, 1985), hal. 1.

${ }^{6}$ Herowati Poesoko, "Parate Executie Obyek Hak Tanggungan (Inkonsistensi, Konflik Norma, dan Kesesatan Penalaran dalam UUHT)", (Yogyakarta: LaksBang PRESSindo,2007), hal. 131.

${ }^{7}$ Ibid.

${ }^{8}$ Ibid., hal. 136. 


\section{Pembebanan HT}

Berdasarkan UUHT, proses pembebanan HT dilaksanakan melalui 2 (dua) tahap yaitu:

\section{Tahap Pemberian HT}

Tahap-tahap tersebut terdiri dari:

a. Pemberian HT didahului dengan janji untuk memberikan HT sebagai jaminan pelunasan utang tertentu yang dituangkan di dalam dan merupakan bagian tak terpisahkan dari perjanjian utang piutang yang bersangkutan atau perjanjian kredit yang bersangkutan atau perjanjian lainnya yang menimbulkan utang tersebut. (Pasal 10 Ayat (1) UUHT). Apabila pemberi HT atau kreditur berhalangan hadir dalam pelaksanaan pemberian dan penandatanganan HT maka kreditur dapat memberikan kuasanya kepada pihak lain. Pemberian kuasa tersebut wajib dilakukan di depan Notaris atau PPAT dengan suatu akta otentik yang disebut Surat Kuasa Membebankan Hak Tanggungan ("SKMHT") dimana bentuk dan isinya ditetapkan dengan Peraturan Menteri Negara Agraria/Kepala BPN Nomor 3 Tahun 1996. SKMHT tersebut sah apabila memenuhi ketentuan yang terdapat dalam Pasal 15 ayat (1) sebagai berikut: ${ }^{11}$

a. SKMHT dilarang memuat kuasa untuk melakukan perbuatan hukum lain daripada membebankan HT, tidak dilarang memberi kuasa memberikan janjijanji yang dimaksudkan dalam Pasal 11 Ayat (2) UUHT;

b. Dilarang memuat kuasa substitusi;

c. Wajib dicantumkan secara jelas obyek HT, jumlah utang, nama serta identitas debitur, apabila debitur bukan pemberi HT.

Apabila persyaratan tersebut dilanggar maka SKMHT tersebut batal demi hukum. Kuasa tersebut berakhir

\footnotetext{
"Boedi Harsono, Op. Cit., hal. 445-446.
} 
apabila telah habis jangka waktunya. Untuk obyek HT yang sudah didaftar maka selambat-lambatnya satu bulan sesudah diberikan, wajib diikuti dengan pembuatan APHT yang bersangkutan. Apabila obyek HT belum didaftar maka jangka waktu penggunaan SKMHT dibatasi selama tiga bulan, dikarenakan untuk keperluan pembuatan APHT diperlukan penyerahan lebih banyak surat-surat dokumen kepada PPAT. Selain itu, jangka waktu tiga bulan tersebut dapat pula diberlakukan kepada obyek HT yang sudah bersertipikat akan tetapi belum tercatat atas nama kreditur. ${ }^{12}$ Apabila SKMHT tidak diikuti dengan pembuatan APHT maka SKMHT batal demi hukum.

a. Tahap selanjutnya adalah pembuatan Akta APHT oleh PPAT sesuai dengan peraturan perundang-undangan yang berlaku ${ }^{13}$ (Pasal 10 Ayat (2) UUHT). Pemberian Hak Tanggungan tersebut wajib memenuhi syarat spesialitas yang meliputi: nama dan identitas pemegang dan pemberi Hak Tanggungan, domisili para pihak, pemegang dan pemberi Hak Tanggungan, penunjukan secara jelas utang atau utang-utang yang dijaminkan pelunasannya dengan Hak Tanggungan, nilai tanggungan, dan uraian yang jelas mengenai objek Hak Tanggungan. (Pasal 11 Ayat (1) UUHT).

b. Dalam APHT dapat dicantumkan janji - janji fakultatif yang terdapat dalam Pasal 11 Ayat (2), ${ }^{14}$ yang berbunyi sebagai berikut:

a. Janji yang membatasi kewenangan pemberi Hak Tanggungan untuk menyewakan obyek HT dan/atau menentukan atau mengubah jangka waktu sewa dan/atau menerima uang sewa di muka, kecuali dengan persetujuan tertulis terlebih dahulu dari pemegang HT.

b. Janji yang membatasi kewenangan pemberi HT untuk mengubah bentuk atau tata susunan obyek

${ }^{12}$ Ibid., hal. 446.

13 Bentuk dan isi dari APHT ditetapkan dengan Peraturan Menteri Negara Agraria/Kepala BPN Nomor 3 Tahun 1996 dikutip dari buku Boedi Harsono, Op. Cit., hal. 432.

${ }^{14}$ Boedi Harsono, Op. Cit., hal. 439. 
HT, kecuali dengan persetujuan tertulis terlebih dahulu dari pemegang HT.

c. Janji yang memberikan kewenangan kepada pemegang HT untuk mengelola obyek HT berdasarkan penetapan Ketua Pengadilan Negeri yang daerah hukumnya meliputi letak obyek HT apabila debitur sungguh-sungguh cidera janji.

d. Janji yang memberikan kewenangan kepada pemegang HT untuk menyelamatkan obyek HT, jika hal itu diperlukan untuk pelaksanaan eksekusi atau untuk mencegah menjadi hapusnya atau dibatalkannya hak yang menjadi obyek Hak Tanggungan karena tidak dipenuhi atau dilanggarnya ketentuan undang-undang.

e. Janji bahwa pemegang HT pertama mempunyai hak untuk menjual atas kekuasaan sendiri obyek HT apabila debitur cidera janji.

f. Janji yang diberikan oleh pemegang HT pertama bahwa obyek HT tidak akan dibersihkan dari HT.

g. Janji bahwa pemegang HT akan memperoleh seluruh atau sebagian dari ganti rugi yang diterima pemberi HT untuk pelunasan piutangnya apabila obyek HT dilepaskan haknya oleh pemberi HT atau dicabut haknya untuk kepentingan umum.

h. Janji bahwa pemegang HT akan memperoleh seluruh atau sebagian dari uang asuransi yang diterima pemberi HT untuk pelunasan piutangnya, jika obyek HT diasuransikan.

i. Janji bahwa pemberi HT akan mengosongkan obyek HT pada waktu eksekusi HT (Pasal 11 Ayat (2) UUHT).

walaupun janji-janji tersebut bersifat fakultatif akan tetapi janji tersebut wajib dihubungkan dengan Pasal 6 UUHT, sehingga menurut Prof. Boedi Harsono terdapat janji-janji fakultatif yang wajib dicantumkan seperti pada Pasal 11 Ayat (2) huruf (e), janji tersebut tidak berdiri sendiri, tetapi melengkapi dan karenanya harus dihubungkan dan merupakan satu kesatuan dengan ketentuan Pasal 6 UUHT yang berbunyi:

Apabila debitur cidera janji, pemegang Hak Tanggungan pertama mempunyai hak untuk menjual 
obyek Hak Tanggungan atas kekuasaan sendiri melalui pelelangan umum serta mengambil pelunasan piutangnya dari hasil penjualan tersebut. Janji tersebut diperlukan untk memenuhi persyaratan yuridis dalam melaksanakan hak pemegang HT yang bersangkutan, yang ditetapkan dalam Pasal 6 tersebut. ${ }^{15}$

Selain itu, terdapat janji yang dilarang untuk dicantumkan dalam APHT yaitu apabila yang diperjanjikan bahwa pemegang Hak Tanggungan akan memiliki objek HT apabila debitur cidera janji (Pasal 12 UUHT) maka APHT tersebut batal demi hukum. ${ }^{16}$

Adapun dalam pelaksanaan pemberian HT tersebut terdapat proses pembebanan HT yang tidak sama dikarenakan status tanah yang dijadikan jaminan hutang dengan Hak Tanggungan, proses pembebanannya adalah sebagai berikut: ${ }^{17}$

1) Status tanah yang masih dalam proses permohonan Sertipikat Hak Guna Bangunan (SHGB) Induk untuk terdaftar atas nama penyelenggara pembangunan atau dengan perkataan lain tanah tersebut belum ada haknya sehingga status tanahnya adalah tanah Negara, proses pembebanannya adalah sebagai berikut:

Penyelenggara pembangunan harus melakukan proses-proses hukum di bawah ini:

a. Pada saat penandatanganan perjanjian kredit antara debitur dan bank, penyelenggara pembangunan harus menyerahkan perjanjian pengikatan jual beli (PPJB) yang telah ditandatangani debitur dan penyelenggara pembangunan beserta surat pernyataan dari debitur yang menjamin bahwa debitur akan menandatangani: SKMHT atau APHT dihadapan PPAT yang ditunjuk

${ }^{15}$ Ibid.

${ }^{16}$ Boedi Harsono, Op. Cit., hal. 440.

17 Arie S. Hutagalung ,"Tebaran Pemikiran Seputar Masalah Hukum Tanah", (Jakarta: Lembaga Pemberdayaan Hukum Indonesia, 2005), hal. 330-332, (selanjutnya disebut Arie S Hutagalung I). 
oleh kreditur pada saat penandatanganan Akta Jual Beli (AJB). Penandatanganan surat pernyataan tersebut dilakukan untuk memberikan jaminan kepada kreditur bahwa pada saat penandatanganan AJB dilakukan, debitur bersedia menandatangani APHT walaupun sertipikat tanah yang ada masih berupa SHGB Induk (atas nama penyelenggara pembangunan).

b. Apabila SHGB Induk telah diperoleh maka penyelenggara pembangunan harus menyiapkan AJB yang dibuat dihadapan PPAT, menandatanganinya bersama-sama dengan debitur serta menyerahkan AJB tersebut kepada bank dalam waktu yang ditentukan setelah selesainya SHGB induk.

c. Dengan berlakunya UUHT, maka pada tahap penandatanganan AJB diatas, debitur juga dimungkinkan untuk menandatangani APHT atas bagian tanah yang dibelinya, walaupun pada saat itu sertipikat tanahnya masih belum dibalik nama ke atas nama debitur yang bersangkutan. Untuk memenuhi asas spesialitas yang disyaratkan UUHT, maka APHT atas SHGB Induk tersebut harus dilampiri dengan gambar situasi dari bagian tanah yang dibeli debitur tersebut.

d. Satu hal yang perlu diperhatikan adalah walaupun secara hukum penandatanganan APHT sebelum terbitnya SHGB atas nama debitur tersebut dimungkinkan, namun pada praktek hal ini sangat tergantung dari kebijaksanaan/keyakinan Notaris/PPAT yang bersangkutan dan juga kebijaksanaan dari Kantor Pertanahan setempat. Untuk mengantisipasi hal tersebut (apabila penandatangan APHT tidak dapat dilakukan pada saat penandatanganan AJB), maka dalam perjanjian pemberian jaminan (PPJ) dicantumkan pula klausul yang menyatakan bahwa apabila karena sesuatu hal penandatanganan APHT pada saat penandatanganan AJB tersebut tidak dimungkinkan, maka debitur akan menandatangani surat pernyataan yang menyatakan bahwa debitur akan menandatangani APHT atas sertipikat pecahan yang dialihkan ke atas nama masingmasing debitur berdasarkan AJB dan menyerahkan SKMHT/APHT, apabila sertipikat pecahan tersebut telah keluar. 
2) Status tanah adalah tanah Hak guna Bangunan (HGB) atas nama penyelenggara pembangunan, atau dengan perkataan lain penyelenggara pembangunan telah memperoleh SHGB Induk tetapi pemecahan dan pendaftaran jual beli masih dalam proses, maka penyelenggara pembangunan melakukan proses yang lebih sederhana yaitu pada saat penandatanganan perjanjian kredit antara debitur dan kreditur maka penyelenggara pembangunan harus menyerahkan AJB yang telah ditandatangani oleh debitur dan penyelenggara pembangunan serta APHT atas SHGB Induk yang dilampiri dengan gambar situasi dari bagian tanah yang diberi oleh debitur. Jadi, dalam hal ini debitur tidak perlu terlebih dahulu menandatangani surat pernyataan sebagaimana pada status tanah sebelumnya.

3) Sertipikat tanah yang dijadikan jaminan hutang jangka waktunya lebih pendek dari jangka waktu pemberian kredit, maka dapat diperjanjikan dalam APHT bahwa pemberi HT memberikan kewenangan kepada pemegang HT untuk atas biaya pemberi HT mengurus perpanjangan hak atas tanah yang dijadikan obyek HT untuk mencegah hapusnya HT karena hapusnya hak atas tanah.

4) HGB atau Hak Pakai (HP) yang diperoleh atas dasar Hak Pengelolaan (HPL) instansi pemerintah atau BUMN atau dengan perkataan lain HGB atau Hak Pakai diatas Hak Pengelolaan, maka apabila pemegang HGB atau Hak Pakai tersebut ingin menjadikan tanahnya sebagai jaminan hutang harus terlebih dahulu mendapat izin dari pemegang Hak Pengelolaan.

\section{Pendaftaran HT}

HT akan lahir apabila telah dilakukan pendaftaran sebagaimana yang dimaksud dalam Pasal 13 UUHT. Pendaftaran tersebut dilakukan oleh PPAT dengan mengirimkan APHT dengan warkah-warkah lain yang diperlakukan ke Kantor Pertanahan untuk didaftarkan selambat-lambatnya 7 (tujuh) hari setelah penandatanganan APHT. ${ }^{18}$ Setelah dilakukan pendaftaran

${ }^{18}$ Arie S Hutagalung, "Serba Aneka Masalah Tanah Dalam Kegiatan Ekonomi (Suatu Kumpulan Karangan)", (Depok: Badan Penerbit Fakultas Hukum Universitas Indonesia,2002), hal. 230, (selanjutnya disebut Arie S Hutagalung II). 
tersebut maka HT telah memenuhi syarat publisitas sebagai salah satu syarat dari lahirnya HT. Setelah pendaftaran tersebut dalam waktu 7 (tujuh) hari setelah dibuatnya Buku Tanah Hak Tanggungan maka Kepala Kantor Pertanahan menerbitkan Sertipikat HT sebagai tanda bukti adanya HT (Pasal 13 Ayat (2) UUHT). Pada Sertipikat HT tersebut terdapat irah-irah "DEMI KEADILAN BERDASARKAN KETUHANAN YANG MAHA ESA" dimana irah-irah tersebut mempunyai kekuatan eksekutorial yang sama dengan putusan pengadilan yang telah mempunyai kekuatan hukum tetap dalam pelaksanaan parate executie atas hak atas tanah obyek HT dan HMSRS. ${ }^{19}$

\section{E. Beralihnya Hak Tanggungan}

Perjanjian jaminan HT bersifat accesoir maka peralihan HT mengikuti peralihan perjanjian utang-piutang sebgai perjanjian pokoknya. HT dapat beralih disebabkan oleh $\mathrm{Cessie}^{20}$, Subrogasi ${ }^{21}$, pewarisan atau sebab-sebab $\operatorname{lain}^{22}$ (Pasal 16 UUHT). Peralihanperalihan tersebut wajib didaftarkan di Kantor Pertanahan setempat.

Pendaftaran beralihnya HT dilakukan oleh Kantor Pertanahan dengan mencatatnya pada buku tanah HT dan buku-buku hak atas tanah yang menjadi obyek HT serta menyalin catatan tersebut pada sertipikat hak atas tanah yang bersangkutan. Tanggal pencatatan adalah tanggal hari ketujuh setelah diterimanya secara lengkap suratsurat yang diperlukan bagi pendaftaran beralihnya HT dan jika hari ke7 (ke tujuh) itu jatuh pada hari libur maka catatan itu diberi bertanggal hari kerja berikutnya.

Beralihnya HT mulai berlaku bagi pihak ketiga pada hari tanggal pencatatan.

${ }^{19}$ Ibid., hal. 450.

${ }^{20}$ Cessie adalah perbuatan hukum mengalihkan piutangoleh kreditur pemegang HT kepada pihak lain.

${ }^{21}$ Subrogasi adalah penggantian kreditur oleh pihak ketiga yang melunasi utang debitur.

${ }^{22}$ Sebab-sebab lain adalah pengambilalihan atau penggabungan perusahaan sehingga menyebabkan beralihnya piutang perusahaan semula kepada perusahaan yang baru. 


\section{F. Hapusnya Hak Tanggungan}

Berdasarkan Pasal 18 UUHT, HT hapus karena hal-hal sebagai berikut:

1. Hapusnya utang yang dijamin dengan HT; dilepaskannya HT oleh pemegang HT; pembersihan HT berdasarkan penetapan peringkat oleh Ketua Pengadilan Negeri; hapusnya hak atas tanah yang dibebani HT.

2. Hapusnya HT karena dilepaskan oleh pemegangnya dilakukan dengan pemberian pernyataan tertulis mengenai dilepaskannya HT tersebut oleh pemegang HT kepada pemberi HT.

3. Hapusnya HT karena pembersihan HT berdasarkan penetapan peringkat oleh Ketua Pengadilan Negeri terjadi karena permohonan pembeli hak atas tanah yang dibebani Hak Tanggungan tersebut agar hak atas tanah yang dibelinya itu dibersihkan dari beban HT sebagaimana diatur dalam Pasal 19.

4. Hapusnya HT karena hapusnya hak atas tanah yang dibeban HT tidak menyebabkan hapusnya utang yang dijamin.

\section{G. Roya Partial}

HT mempunyai sifat yang tidak dapat dibagi kecuali jika diperjanjikan dalam APHT. Selain itu, pelunasan utang dapat dilakukan dengan cara angsuran yang besarnya sama dengan nilai masing-masing hak atas tanah yang merupakan bagian obyek HT.

Keistimewaan lembaga ini adalah bahwa bangunan yang pada saat HT dibebankan belum ada, dapat dibebani HT. Tetapi semuanya harus diperjanjikan secara tegas dalam APHT yang bersangkutan. ${ }^{23}$

\section{H. Eksekusi Hak Tanggungan}

Eksekusi HT diatur dalam Pasal 20 UUHT, sehingga dapat dikatakan terdapat beberapa cara pelaksanaan eksekusi HT, yaitu ${ }^{24}$ :

\footnotetext{
${ }^{23}$ Arie S Hutagalung, Bahan Ajar Secured Transaction.

${ }^{24}$ Boedi Harsono, Op. Cit., hal. 458-460.
} 


\section{Parate Executie}

Secara etimologis parate executie berasal dari kata paraat artinya siap di tangan sehingga parate executie dikatakan sebagai sarana eksekusi yang siap di tangan. ${ }^{25}$

Menurut kamus hukum, parate executie mempunyai arti pelaksanaan yang langsung tanpa melewati proses (pengadilan atau hakim) ${ }^{26}$

Arti parate executie yang diberikan doktrin adalah "kewenangan untuk menjual atas kekuasaan sendiri atau parate eksekusi, diberikan arti, bahwa apabila debitur cidera janji, kreditur dapat melaksanakan eksekusi obyek jaminan, tanpa harus minta fiat dari Ketua Pengadilan. ${ }^{27}$

Subekti $^{28}$ berpendapat parate executie adalah menjalankan sendiri atau mengambil sendiri apa yang menjadi haknya, dalam arti tanpa perantaraan hakim, yang ditujukan atas sesuatu barang jaminan untuk selanjutnya menjual sendiri barang tersebut.

Pada Pasal 20 Ayat (1) huruf (a) UUHT dinyatakan bahwa apabila debitur cidera janji maka pemegang HT pertama untuk menjual obyek HT sebagaimana diatur dalam Pasal 6 UUHT, unsur-unsur tersebut yang terjalin menjadi esensi dalam Pasal 6 UUHT tersebut, adalah :

a. Debitur cidera janji;

b. Kreditur pemegang HT pertama diberi hak;

c. Hak untuk menjual obyek HT atas kekuasaan sendiri;

d. Syarat penjualan melalui pelelangan umum;

e. Hak kreditur mengambil pelunasan piutangnya dari hasil penjualan;

${ }^{25}$ J. Satrio, "Hukum Jaminan, Hak Jaminan Kebendaan, Hak Tanggungan Buku 2", hal. 276 dikutip dari Herowati Poesoko, Op. Cit., hal. 241.

${ }^{26}$ Kamus Hukum Edisi Lengkap, Bahasa Belanda-Indonesia-Inggris, (Semarang: Aneka, 1977), hal. 655, dikutip dari Herowati Poesoko, Ibid.

${ }^{27}$ V. Nierop, 1937, hal 153, "Hypotheekrech", Cetakan kedua, Tjeenk Willink, Zwolle dikutip dari Herowati, Ibid.

${ }^{28}$ Subekti, "Pelaksanaan Perikatan,Eksekusi Riil dan Uang Paksa, dalam Penemuan Hukum dan Pemecahan Masalah Hukum,Proyek Pengembangan Teknis Yustisisal", (Jakarta: MARI,1990), hal. 69, dikutip dari Herowati Poesoko. 
f. Hak kreditur mengambil pelunasan piutangnya sebatas hak tagih. ${ }^{29}$

Pasal 6 UUHT ini memberikan kemudahan dan efektifitas waktu tanpa harus meminta fiat Ketua Pengadilan Negeri karena eksekusi hanya dilakukan dengan pelelangan umum dan dengan adanya Pasal 6 UUHT ini maka kreditur akan terlindungi dari perbuatan debitur yang tidak layak atau bahkan tidak mempunyai itikad baik sehingga pasal tersebut sebagai tiang penyanggah utama bagi kreditur dalam memperoleh percepatan pelunasan piutangnya agar piutang yang telah kembali pada kreditur kemudian keuangan tersebut dapat digunakan untuk perputaran roda perekonomian. ${ }^{30}$ Eksekusi yang didasarkan Pasal 6 UUHT dimana diberikannya kemudahan bagi kreditur pemegang HT dalam pelaksanaan eksekusi HT dikarenakan kreditur pemegang HT tersebut mempunyai kedudukan yang istimewa dalam bentuk droit de preference dan droit de suite yang merupakan ciri-ciri dari HT. ${ }^{31}$ Sehingga apabila debitur cidera janji, kreditur pemegang HT dapat langsung mengajukan permintaan kepada Kepala Kantor Lelang Negara untuk melakukan penjualan obyek HT yang bersangkutan.

Pelaksanaan lelang parate executie ini telah diatur dalam Surat Edaran Badan Urusan Piutang dan Lelang Negara Nomor SE-21/PN/1998 Tentang Petunjuk Pelaksanaan Pasal 6 UUHT dalam Angka 1 yang menyatakan bahwa "...penjualan tersebut bukan secara paksa, tetapi merupakan tindakan pelaksanaan perjanjian oleh pihak-pihak. Oleh karena itu tidak perlu raguragu lagi melayani permintaan lelang dari pihak perbankan atas obyek HT berdasarkan Pasal 6 UUHT" serta pada Angka 3 yang menyatakan bahwa "lelang obyek HT berdasarkan Pasal 6 UUHT adalah tergolong lelang sukarela..." dan dipertegas oleh Surat Edaran Badan Urusan Piutang dan Lelang Negara Nomor SE23/PN/2000 butir 1a huruf (e) yang menyatakan bahwa "Pelaksanaan lelang HT sebagaimana dimaksud Pasal 6 UUHT

${ }^{29}$ Herowati Poesoko, Op. Cit., hal. 246.

${ }^{30}$ Ibid., hal. 248.

${ }^{31}$ Boedi Harsono, Op. Cit., hal. 455. 
tidak diperlukan persetujuan debitur untuk pelaksanaan lelangnya." ${ }^{32}$

Perkembangan selanjutnya pelaksanaan lelang tersebut dipertegas dengan Surat Menteri Keuangan Nomor 304/KMK.01/2002 tertanggal 13 Juni 2002 tentang Petunjuk Pelaksanaan Lelang yang dalam Pasal 2 Ayat (3) menyebutkan bahwa "Kantor lelang tidak boleh menolak permohonan lelang yang diajukan kepadanya sepanjang persyaratan lelang sudah dipenuhi." Selanjutnya peraturan pelaksanaan tersebut ditindaklanjuti dengan adanya Keputusan Direktur Jenderal Piutang dan Lelang Negara Nomor 35/PL/2002 tertanggal 27 Januari 2002 tentang Petunjuk Teknis Pelaksanaan Lelang.

Dari beberapa peraturan tersebut, semakin memperjelas pelaksanaan hak kreditur pertama pemegang HT untuk menjual obyek HT atas kekuasaan sendiri melalui lelang (parate executie) yang dilaksanakan oleh Kantor Lelang Negara. ${ }^{33}$

\section{Titel Eksekutorial}

Pelaksanaan titel eksekutorial ini masih menggunakan Hukum Acara Perdata produk Belanda yang diatur dalam Pasal 224 HIR dan 258 RBg, hal ini didasarkan pada ketentuan Pasal 26 UUHT yang menyatakan bahwa sebelum ada peraturan perundang-undangan yang mengatur secara khusus eksekusi HT maka peraturan mengenai eksekusi Hypotheek berlaku terhadap eksekusi HT. Dalam pelaksanaan eksekusi tersebut harus diperhatikan ketentuan Pasal 14 UUHT yang menyatakan bahwa Sertipikat HT berlaku sebagai pengganti grosse acte hypotheek sepanjang mengenai hak atas tanah yang menjadi obyek HT, HMSRS. Pelaksanaan eksekusi tersebut dilaksanakan dengan mengajukan permohonan eksekusi oleh kreditur pemegang HT kepada Ketua Pengadilan Negeri setempat dengan menyerahkan sertipikat HT sebagai dasarnya. Kemudian, eksekusi akan dilaksanakan atas perintah dan dengan pimpinan Ketua Pengadilan Negeri yang bersangkutan melalui pelelangan umum yang dilakukan oleh Kantor Lelang Negara. ${ }^{34}$

${ }^{32}$ Herowati Poesoko, Op. Cit., hal. 299-300.

${ }^{33}$ Ibid., hal. 301-302. 
3. Selain kedua pelaksanaan eksekusi HT tersebut, UUHT juga memperkenalkan penjualan di bawah tangan dalam rangka eksekusi dengan syarat apabila melalui pelelangan umum diperkirakan tidak akan menghasilkan harga tertinggi atas kesepakatan pemberi dan pemegang HT dan dengan dipenuhinya syarat-syarat yang terdapat dalam Pasal 20 Ayat (2) dan (3) yang berbunyi " ayat (2) Atas kesepakatan pemberi dan pemegang Hak Tanggungan, penjualan obyek Hak Tanggungan dapat dilaksanakan di bawah tangan jika dengan demikian itu akan dapat diperoleh harga tertinggi yang menguntungkan semua pihak; (3) Pelaksanaan penjualan sebagaimana dimaksud pada Ayat (2) hanya dapat dilakukan setelah lewat waktu 1 (satu) bulan sejak diberitahukansecara tertulis oleh pemberi dan/atau pemegang Hak Tanggungan kepada pihak-pihak yang berkepentingan dan diumumkan sedikit-dikitnya dalam 2 (dua) surat kabar yang beredar di daerah yang bersangkutan dan/atau media massa setempat, serta tidak ada pihak yang menyatakan keberatan.

Penjualan obyek HT "dibawah tangan" tersebut tidak melalui pelelangan umum akan tetapi tetap harus dilakukan berdasarkan ketentuan PP Nomor 24 Tahun 1997 tentang Pendaftaran Tanah, yaitu dengan cara dilakukan di hadapan PPAT yang membuat aktanya dan dilakukannya pendaftaran di Kantor Pertanahan setempat. $^{35}$

\section{Tahap-tahap pelaksanaan Eksekusi HT}

Eksekusi HT berdasarkan Pasal 224 HIR sebagai berikut: ${ }^{36}$

\section{Tahap Permohonan}

a. Kreditur mengajukan eksekusi pada Pengadilan Negeri dimana barang jaminan tersebut terletak atau Pengadilan

\footnotetext{
${ }^{34}$ Boedi Harsono, Op. Cit., hal. 457.

${ }^{35}$ Boedi Harsono, Ibid., hal. 458-459.

${ }^{36}$ Arie S Hutagalung I, Op. Cit., hal. $235-237$.
} 
Negeri dimana barang jaminan tersebut terletak atau Pengadilan Negeri yang dalam perjanjian ditetapkan sebagai domisili hukum.

b. Pengadilan akan memanggil/menegur debitur (aanmaning) sebanyak dua kali dengan tenggang waktu 8 (delapan) hari untuk tiap-tiap aanmaning yang diterima.

c. Debitur dapat mempunyai tiga sikap terhadap aanmaning tersebut, yaitu:

i) Tidak mempedulikan;

ii) Mengakui hutang dan besar jumlah hutangnya; dalam hal demikian, kreditur dapat langsung meminta pembayaran seluruh jumlah hutang atau meminta kerjasama debitur untuk menjual jaminan guna melunasi seluruh jumlah hutangnya;

iii) Debitur mengajukan bantahan. Bantahan ini dapat mengenai jumlah hutangnya yang tidak dapat sesuai dengan catatan debitur atau mengenai barang jaminan. Sering sekali barang jaminan itu terdaftar atas nama isteri atau suami debitur dan dianggap digunakan sebagai jaminan tanpa persetujuan isteri atau suami. Kemudian istri/suami yang bersangkutan membantah bahwa ia tidak pernah setuju menggunakan tanah dan rumah sebagai jaminan. Dapat juga ternyata istri/suami yang sah yang dibuktikan dengan adanya surat nikah/akta perkawinan. Dalam keadaan demikian eksekusi ditunda sampai ada keputusan perkara bantahan tesebut.

\section{Tahap Penyitaan}

a. Kreditur mengajukan permohonan sita atas jaminan yang dilelang.

b. Pengadilan akan mengeliarkan penetapan sita yang kemudian dilanjutkan dengan proses penyitaan oleh petugas pengadilan yang dibuktikan dengan Berita Acara Penyitaan. Apabila tidak ada tanggapan dari debitur maka proses akan dilanjutkan. 


\section{Tahap Pelelangan}

a. Kreditur mengajukan permohonan lelang kepada Pengadilan Negeri.

b. Pengadilan akan memuat ketetapan lelang dan menetapkan waktu lelang setelah berkonsultasi dengan Kantor Lelang.

c. Sebelum lelang dilaksanakan ada dua syarat yang harus dipenuhi kreditur:

i) Kreditur memberitahukan Pengadilan mengenai plafond harga (harga minimal) dari barang jaminan.

ii) Kreditur meminta Surat Keterangan Pendaftaran Tanah (SKPT) dari barang jaminan kepada Kantor Pertanahan setempat.

d. Acara lelang dilaksanakan di Pengadilan Negeri setempat. Pembeli harus sekurang-kurangnya 2 (dua) orang pihak, apabila tidak ada peminat, maka lelang ditunda kurang lebih satu bulan dan harus didahului dengan pemasangan iklan sebanyak 1 (satu) kali.

Pelelangan obyek HT dari kedua eksekusi tersebut dapat dihindari dengan pelunasan utang yang dijamin berikut biaya-biaya eksekusi yang telah dikeluarkan sampai dengan dikeluarkannya pengumuman lelang.

\section{J. Hambatan-Hambatan Dalam Pelaksanaan Eksekusi Hak Tanggungan}

Dalam pelaksanaannya, eksekusi HT mengalami hambatanhambatan yang berasal dari i) pihak kreditur seperti membuat plafon terlalu rendah, sehingga ditolak Ketua Pengadilan Negeri, Tidak menyiapkan pembeli, tidak menyiapkan harga lelang, berdamai dengan debitur sebelum lelang; ii) pengadilan seperti ditunda KPN dengan alasan plafon tidak tercapai, ada bantahan, debitur memohon tanda dikabulkan; Surat KPT; Surat MARI; Telepon MARI: iii) dari debitur itu sendiri seperti menggugatgugatan, membantah - bantahan, meminta fatwa ke PT, meminta fatwa ke MA, menghalangi lelang dengan pembeli-pembeli fiktif. ${ }^{37}$

${ }^{37}$ Arie S Hutagalung II, Op. Cit., hal. 238. 
Selain itu terdapat pula hambatan-hambatan lainnya dalam pelaksanaan hak kreditur sebagai pemegang hak preference atas HT sering mengalami beberapa masalah antara lain: ${ }^{38}$

1. Proses permohonan sampai dengan penerimaan hasil lelang memerlukan waktu yang panjang dan pemantauan yang terus menerus;

2. Dengan berlakunya asas negatif ${ }^{9}$ maka apabila tanah tersebut telah dijadikan jaminan dan dapat dibuktikan bahwa pemberi HT bukan pemilik sebenarnya tentulah mengakibatkan pembatalan penggunaan hak atas tanah tersebut sebagai jaminan dan dengan demikian menyebabkan adanya resiko bagi bank.

3. Dengan berlakunya asas horizontal dapat menimbulkan bermacam kendala seperti :

a. Bila tanah dimaksud dibebani HT kemudian ada kemungkinan debitur tersebut mendapatkan mesinmesin yang diatanam diatas tanah itu dari perusahaan leasing dan tidak terbayar kewajibannya kepada perusahaan leasing, tanah dan pabrik itu dapat dimintakan untuk disita tanpa memperhatikan kepentingan bank sebagai kreditur pemegang HT.

Memang dapat saja bank melakukan upaya bantahan dan upaya lain sebagainya, namun sedikit banyak pinjaman/bank telah terganggu dan dalam penanganannya membutuhkkan tenaga serta biaya yang seharusnya tidak perlu terjadi.

b. Demikian pula kreditur harus teliti untuk meyakinkan dirinya bahwa pemilik tanah adalah sama dengan pemilik bangunan. Kalau bank melakukan kesalahan dan akibatnya menerima jaminan yang bukan haknya maka tentunya bank akan mengalami kesulitan dalam mengeksekusinya.

c. Bila debitur bank adalah pemilik bangunan dan bukan pemilik tanah tentunya kreditur bank harus mengetahui terlebih dahulu hubungan hukum antara pemilik tanah

${ }^{38}$ Arie S Hutagalung I, Op. Cit., hal. 336-337.

${ }^{39}$ Asas Negatif adalah seseorang yang namanya tercantum di dalam suatu sertipikat atas tanah tersebut dianggap selaku pemilik yang asah atas tanah namun sepanjang dapat dibuktikan sebaliknya oleh pihak lain maka dengan suatu keputusan Pengadilan kepemilikan tanah itu dapat dibatalkan. 
dan pemilik bangunan dan kreditur harus mengusahakan agar kreditur tersebut mempunyai kedudukan preference atas bangunan itu sehingga jika terjadi kredit macet dan akan dieksekusi maka tidakakan menimbulkan bantahan dari pemilik tanahnya.

4. Tidak adanya persetujuan suami/isteri atau Komisaris/ Pemegang Saham akan menimbulkan bantahan yang menghambat jalannya eksekusi.

5. Sertipikatnya aspal atau palsu maka eksekusi tidak dapat dilaksanakan.

6. Tanah yang dibebani HT sedang dalam sengketa sehingga proses eksekusi akan ditangguhkan sampai perkara mengenai tanah tersebut diselesaikan.

7. Tanah dimaksud sedang disita Pengadilan sehingga eksekusi baru dapat dijalankan bila sita tersebut telah diasngkat terlebih dahulu.

8. Apabila isteri atau suami dari pemilik tanah yang dibebani HT adalah Warga Negara Asing maka hak atas tanah yang dibebani HT itu akan dialihkan kepada orang lain atau HT tersebut akan ikut hapus dengan hapusnya hak atas tanahnya.

\section{K. Kesesatan Penjelasan Umum UUHT}

Bertitik tolak dari model kesesatan yang digunakan dalam menganalisis Penjelasan Umum Angka 9 UUHT, yang dikaitkan dengan konsep hukum dalam Pasal 6 UUHT yang merupakan tujuan Pembentuk UUHT berkehendak untuk mewujudkan kemudahan yang disediakan oleh undang-undang bagi kreditur pemegang HT pertama dalam rangka pelaksanaan penjualan oleh HT atas kekuasaan sendiri melalui pelelangan umum, manakala debitur cidera janji, tertuang dalam Pasal 20 Ayat (1) huruf (a) UUHT, menyatakan:

"a. Hak pemegang HT pertama untuk menjual obyek HT sebagaimana dimaksud dalam Pasal 6, atau ...".

Namun, apabila membaca Penjelasan Umum Angka 9 UUHT yang menyatakan bahwa:

Salah satu ciri Hak Tanggungan yang kuat adalah mudah dan pasti dalam pelaksanaan eksekusinya, jika debitor cidera janji. Walaupun secaraumum ketentuan 
tentang eksekusi telah diatur dalam Hukum Acara Perdata yang berlaku, dipandang perlu untuk memasukkan secara khusus ketentuan tentang eksekusi Hak Tanggungan dalam Undang-Undang ini, yaitu yang mengatur lembagaparate executie sebagaimana dimaksud dalam Pasal 224 Reglemen Indonesia yang Diperbarui (Het Herziene Indonesisch Reglement) dan Pasal 258 Reglemen AcaraHukum Untuk Daerah Luar Jawa dan Madura (Reglement tot Regeling van hetRechtswezen in de Gewesten Buiten Java en Madura).

Pemahaman dari Penjelasan Umum Angka 9 tersebut khususnya terhadap lembaga parate executie, menunjukkan kehendak Pembentuk Undang-Undang melalui penafsiran otentik untuk mengatur lembaga parate, maksudnya pengaturan lembaga parate executie masuk dalam ranah Hukum Acara Perdata. ${ }^{40}$

Apabila Penjelasan Umum Angka 9 tersebut dapat ditafsirkan, jika debitur benar-benar wanprestasi, maka pemegang HT pertama dapat melaksanakan janji tersebut dengan menjual lelang obyek HT atas kekuasaan sendiri (parate executie) berdasar pada Pasal $224 \mathrm{HIR} / \mathrm{Pasal} 258 \mathrm{Rbg}$ adalah tidak tepat, hal tersebut sama dengan pendapat Sudikno Mertokusumo, yang menyatakan kiranya kurang tepat jika eksekusi ex-Pasal 224 HIR disebut sebagai parate executie. ${ }^{41}$ Seharusnya pelaksanaan parate executie tidak mendasarkan pada Pasal $224 \mathrm{HIR}$ dan $258 \mathrm{RBg}$., seperti yang disebutkan oleh Penjelasan Umum Angka 9. Melainkan prosedur pelaksana parate executie itu dilaksanakan tanpa meminta fiat dari Ketua Pengadilan Negeri.

Ketentuan mengenai parate executie itu lahir dari suatu janji (beding) yang diberikan oleh pemberi hak jaminan kepada penerima hak, yaitu janji untuk menjual benda jaminan atas kekuasaan (beding van eigenmachtige verkoop) sedangkan yang dimaksud eksekusi berdasarkan Pasal 224 HIR/258 RBg diitujukan sebagai dasar eksekusi bagi grosse acte hipotik dan

${ }^{40}$ Herowati Poesoko, Op. Cit., hal. 269.

${ }^{41}$ Sudikno Mertokusumo,1996, Eksekusi Obyek Hak Tanggungan, Permasalahan dan Hambatan, Makalah Penataran Dosen Hukum Perdata, FH UGM Yogyakarta, 16-23 Juli 1996, hal.8 dikutip dari Herowati Poesoko, Op. Cit., hal. 270. 
grosse acte pengakuan hutang. Kericuhan terhadap pelaksanaan parate executie tersebut, disebabkan Pasal 224 HIR sendiri. Aturan grosse acte pengakuan hutang hanya terdapat dalam Pasal 224 HIR (Pasal 258 RBg) merupakan pasal tunggal dan berdiri sendiri, tidak terdapat aturan lain. Lain halnya dengan grosse acte hipotik yang diatur secara lengkap dan luas dalam Pasal 51 dan Pasal 5 UUPA, Bab XXI Buku Kedua KUHPerdata jo. Peraturan Menteri Agraria Nomor 15 Tahun 1961 jo Peraturan Pemerintah Nomor 10 Tahun 1961, yang telah diubah dengan Peraturan Pemerintah Nomor 24 Tahun 1997 Tentang Pendaftaran Tanah. ${ }^{42}$

Apabila pelaksanaan penjualan lelang (parate executie) atas obyek HT terlebih dahulu harus melalui dan atas perintah Ketua Pengadilan Negeri, maka logika hukumnya pembentuk UUHT selain tidak lagi membedakan antara lembaga parate eksekusi dengan lembaga grosse acte hipotik (sekarang Lembaga Sertipikat Hak Tanggungan) dan lembaga grosse acte Pengakuan Hutang, akibatnya semua lembaga tersebut eksekusinya harus mendapatkan fiat Ketua Pengadilan Negeri yang tunduk pada asas eksekusi Hukum Acara Perdata. Sehingga pengaturan yang demikian menunjukkan sifat Pembentuk UUHT inkonsisten. Sehingga tidak salah jika ada yang berpendapat bahwa norma yang mengatur pelaksanaan parate executie HT merupakan norma yang kabur (vage norman).

Apabila lembaga parate executie disamakan dengan lembaga eksekusi sebagaimana dimaksud dalam Pasal $224 \mathrm{HIR} / 258 \mathrm{RBg}$ yakni harus dilaksanakan atas perintah Ketua Pengadilan Negeri melalui fiatnya, maka untuk menjernihkan perlu mengkonstruksikan secara yuuridis terhadap kedua pasal tersebut. Konstruksi yuridis Pasal 224 HIR/258 RBg menunjukkan pengaturan eksekusi yang ditujukan bagi grosse acte hipotik dan grosse acte pengakuan hutang. Kedua grosse acte tersebut dimaksudkan memang mempunyai titel eksekutorial sehingga mempunyai hak eksekutorial, yang berarti kedua grosse acte tersebut mempunyai kekuatan sebagai suatu putusan pengadilan yang telah berkekuatan hukum tetap. Maka eksekusinya tunduk dan patuh sebagaimana pelaksanaan suatu putusan pengadilan, yang harus dilaksanakan atas perintah Ketua Pengadilan Negeri. Sehingga prosedur pelaksanaan parate executie dengan penjualan lelang obyek HT berdasarkan Pasal 224 HIR/258 RBg 
sebagaimana yang dimaksud dalam Penjelasan Umum Angka 9 UUHT terlebih dahulu melalui dan atas perintah Ketua Pengadilan Negeri. ${ }^{43}$

Namun, Penjelasan Umum tidak dapat digunakan sebagai dasar bagi norma materi pokok yang diatur dalam suatu UndangUndang. Hal tersebut dapat diketahui dari Keputusan Presiden Republik Indonesia Nomor 44 Tahun 1999 Tentang Penyusunan Peraturan Perundang-Undangan dan Bentuk Rancangan UndangUndang, Rancangan Peraturan Pemerintah dan Rancangan Keputusan Presiden tanggal 19 Mei 1999,LN RI Tahun 1999 Nomor 70 ("Keppres 44/1999"), pada II, tentang Hal-Hal Khusus, IIA, Penjelasan dinyatakan.

\section{Pada dasarnya rumusan penjelasan peraturan} perundang-undangan tidak dapat dijadikan sebagai sandaran bagi materi pokok yang diatur dalam batang tubuh. Karena itu, penyusunan rumusan norma dalam batang tubuh harus jelas dan tidak menimbulkan keragu-raguan.

118.Penjelasan tidak dapat digunakan sebagai dasar hukum untuk membuat peraturan lebih lanjut. Karena itu, hindari membuat Rumusan norma di dalam bagian Penjelasan.

\section{Penjelasan berfungsi sebagai tafsiran resmi atas materi tertentu.}

Berdasarkan Keppres 44/1999 tersebut maka Penjelasan Undang-Undang bukanlah norma melainkan sebagai tafsiran resmi dari materi tertentu, sedangkan Penjelasan Umum Angka 9 UUHT tersebut bukan merupakan penjelasan dari materi parate executie melainkan Penjelasan dari materi sertipikat HT. Oleh sebab itu Penjelasan Umum Angka 9 UUHT tidak mempunyai kekuatan berlaku mengikat terhadap pelaksanaan parate executie sebagaimana dimaksud dalam Pasal 6 UUHT. Dengan kata lain, logika hukumnya pelaksanaan atas parate executie HT tidak menggunakan prosedur Hukum Acara Perdata dan tidak diperlukan ijin atau perintah dari Ketua Pengadilan Negeri, 
melainkan cukup dilaksanakan melalui pelelangan umum oleh Kantor Lelang Negara. ${ }^{44}$

\section{Penutup}

Pelaksanaan eksekusi HT yang masih menggunakan produk Belanda yaitu HIR dan Rbg belumlah cukup dikatakan sempurna karena hal tersebut merupakan inkonsistensi dalam reformasi hukum jaminan di Indonesia. Inkonsistensi reformasi hukum jaminan tersebut mengakibatkan timbulnya hambatan-hambatan dalam pelaksanaan eksekusi dikarenakan ketidak sesuaian pengaturan eksekusi dengan perkembangan zaman. Dengan demikian, diperlukannya pengaturan tersendiri dalam sebuah undang-undang perihal hukum acara dari pelaksanaan eksekusi HT yang akan menciptakan harmonisasi antara hukum materiil dan hukum acara atas pelaksanaan jaminan HT. Selain itu, terdapat inkonsistensi Pasal 6 UUHT dengan Penjelasan Umum Angka 9 UUHT atas pelaksanaan dari parate executie obyek HT, Pasal 6 UUHT pada intinya menyatakan bahwa penjualan lelang atas obyek HT dapat dilakukan tanpa meminta fiat Pengadilan, akn tetapi pada Penjelasan Umum Angka 9 UUHT, pelaksanaan penjualan lelang dari parate executie tersebut terlebih dahulu meminta fiat Pengadilan. Berdasarkan Keppres 44/1999 Penjelasan Undang-Undang bukanlah norma melainkan sebagai tafsiran resmi dari materi tertentu, sehingga pelaksanaan lelang obyek HT tersebut tidak melalui fiat Pengadilan.

${ }^{44}$ Ibid., hal. 273. 


\section{Daftar Pustaka}

Harsono, Boedi. Sejarah Pembentukan Undang-Undang Pokok Agraria, Isi dan Pelaksanaannya, Jakarta: Djambatan, 2005.

Hutagalung, Arie S. Serba Aneka Masalah Tanah Dalam Kegiatan Ekonomi (Suatu Kumpulan Karangan), Depok: Badan Penerbit FHUI, 2002.

- Tebaran Pemikiran Seputar Masalah Hukum Tanah, Jakarta: Lembaga Pemberdayaan Hukum Indonesia, 2005.

Indonesia. Undang-Undang Republik Indonesia Nomor 4 Tahun 1996 Tentang Hak Tanggungan Atas Tanah Beserta Benda-benda Yang Berkaitan Dengan Tanah LN. 1996-42, TLN No. 3632.

Poesoko, Herowati. Parate Executie, Obyek Hak Tanggungan (Inkonsistensi, Konflik Norma dan Kesesatan Penalaran dalam UUHT), Yogyakarta: LaksBang PRESSindo, 2007.

Subekti. Hukum Acara Perdata Indonesia, Jakarta: Bina Cipta,1982. . Hukum Perjanjian, Cetakan ke X, Jakarta: PT. Intermasa, 1985.

Tesalonika, Iming. Indonesia Security Interest, Tangerang: Pusat Hukum Bisnis Universitas Pelita Harapan, 2001. 